\title{
Assessment of serum selenium binding protein-1 level in patients with chronic kidney disease: its relation to the renal function and the associated risk factors.
}

\author{
Sazan D. Saeed ${ }^{1}$, Ansam N. Al-Hasani², Marwan S. Al-Nimer ${ }^{2,3 *}$ \\ ${ }^{1}$ Department of Pharmacology and Toxicology, College of Pharmacy, Hawler Medical University, Erbil, Iraq \\ ${ }^{2}$ Department of Clinical Pharmacology, College of Pharmacy, Hawler Medical University, Erbil, Iraq \\ ${ }^{3}$ Department of Dentistry, AL-Rafidain University College, Baghdad, Iraq
}

\begin{abstract}
Selenium-binding protein 1 (SBP-1) is a $56 \mathrm{kD}$ cytosolic protein bound to selenium by selenosulfide covalent bond. It enhances the production of reactive oxygen species and aggravates the oxidative stress. Significant high urinary levels observed in acute kidney injury. This cross-sectional observational study aimed to assess the clinical significant of determining the serum level of SBP-1 in patients with chronic kidney disease (CKD). A total number of 125 patients with established CKD, and 30 healthy subjects were recruited from Rizgary Teaching Hospital in Erbil-Iraq from January to August 2018. Anthropometric, blood pressure, and estimated glomerular filtration rate (eGFR) were determined. Serum SBP-1 was determined by using enzyme linked immunoassay technique. The mean \pm SD of serum SBP-1 level was significantly $(p<0.001)$ higher in CKD than the corresponding level of healthy subjects $(2009 \pm 857.4$ vs. $920.6 \pm 288.3 \mathrm{pg} / \mathrm{ml})$, respectively. Significant positive correlation between eGFR with serum level of SBP-1 $(r=0.188, p=0.036)$ was observed. Receiving operating characteristics test shows that the area under the curve of the waist to height ratio was significantly high at a cut-off value of SBP-1 is $1500 \mathrm{pg} / \mathrm{ml}$. The sensitivity, the specificity, and the positive predictive value of this discriminator were $61.6 \%, 100 \%$, and $77 \%$, respectively. We conclude that serum SBP-1 significantly correlates with eGFR, and it is a useful discriminator of cardiovascular events that represented by a significant the area under the curve of waist to height ratio.
\end{abstract}

Keywords: Selenium binding protein-1, Chronic kidney disease, Estimate glomerular filtration rate.

Accepted on November 21, 2018

\section{Introduction}

Selenium-binding protein-1 (SBP-1, or hSP56 or SBP56) is a $56 \mathrm{kD}$ cytosolic protein and heavily tyrosine-phosphorylated that bound to selenium by selenosulfide covalent bond [1]. It acts as membrane traffic but it does not act as a transmembrane protein [2,3]. It is expressed in all over the body, but its expression in the lung, liver and kidney was higher than other tissues [4,5]. Its role in the selenium metabolism is still unknown, and there is no evidence that it plays a role in the selenium delivery. Some authors believed that selenium itself can induce expression and increasing the levels of SBP-1. Its pharmacological action including suppression of the tumoigenesis in the different organs and it progressively decreased during the development of the cancer [6-10]. SBP-1 is a target of the progression tumor factor called a hypoxia inducing factor- $1 \alpha(\mathrm{HIF}-1 \alpha)$ [11]. Its levels increased in the psychotic illnesses e.g. schizophrenia and autoimmune eye disease e.g., spontaneous equine recurrent uveitis $[12,13]$. There is an inverse relationship between SBP-1 and selenoenzyme glutathione peroxidase-1 (GPx1); it means SBP-1 specifically reduced the activity of GPx1 [14]. There is an interaction between oxidative stress syndrome and SBP-1. Hypoxia induces overproduction of reactive oxygen species (ROS) and expression of HIF-1 $\alpha$ which in turn facilitates the expression of SBP-1. On that occasion the SBP-1 counteracts the activity of GPx1 leading to a further increase levels of ROS [15]. In chronic kidney disease (CKD), generation of (ROS) were increased, and a hemodialysis as a part of management of uremia is contributed in a further production of ROS and a reduction in the antioxidant activity $[16,17]$. In CKD, the extracellular glutathione peroxidase (a selenoprotein antioxidant) notably GPx3 is deficient [18]. Therefore, the circulating level of SBP-1 does not act in this GPx. Recent experimental study demonstrates a significant increase of urinary excretion of SBP-1 with a significant the area under the curve compared with serum creatinine $(\mathrm{SCr})$ or blood nitrogen urea (BNU) in acute kidney injury-model [19]. This crosssectional observational study aimed to evaluate the clinical 
significant of determining the serum level of SBP-1 in CKD patients, and to relate its level to the other indices.

\section{Materials and Methods}

\section{Ethical approval and consent to participate}

The Institutional Scientific Committee at the Hawler Medical University approved this study taking in consideration the guidelines of the Helsinki. According to the guidelines, any drug or device used in this study should be harmless, and the patient is free to withdraw from the study at any time. Patients who were willing to enrol in this study signed a consent form at a time of entry into the study.

\section{Setting}

This cross-sectional study was done in the Department of Pharmacology and Toxicology at the Hawler Medical University in Kurdistan region-Iraq from January to August 2018. The patients were recruited from the Unit of Dialysis at the Rizgary Teaching Hospital in Erbil-Iraq. Eligible patients were both genders of whatever age. The criteria of inclusion were known cases of chronic kidney disease of whatever etiological causes that refereed to the hemodialysis. Patients with chronic renal failure due to terminal illness, intoxication with heavy metals, abnormal electrolytes levels, and complicated pregnancy were excluded from the study.

\section{Sample size estimation}

The sample size was calculated by using margin of errors $(\alpha=0.05, \beta=0.2)$, two tails and $95 \%$ confidence interval. Therefore, the sample size is $=1+2 \mathrm{C} \times$ (Standard deviation/ difference between means) ${ }^{2}$, where $\mathrm{C}$ represents the constant value that derived from the statistical tables and it equals to 7.85 when the $1-\beta=0.8$ and $\alpha=0.05$.

A total number of 125 patients (66 men and 59 women) diagnosed as chronic kidney disease and 30 healthy subjects (16 men and 14 women) were enrolled in the study.

\section{Clinical assessment}

The authors interviewed each patient and obtained a demographic and illness history. Anthropometric measurements including the height $(\mathrm{m})$; weight $(\mathrm{kg})$ and waist circumference $(\mathrm{cm})$. A waist circumference of $\geq 80 \mathrm{~cm}$ (women) and $\geq 90 \mathrm{~cm}$ (men) indicating the presence of central obesity. The body mass index (BMI) was calculated according to the Quetlett's equation:

\section{BMI $\left(\mathrm{kg} / \mathrm{m}^{2}\right)=$ Weight $(\mathrm{kg}) /$ Height $^{2}(\mathrm{~m})$}

Waist height ratio (WHeR) was calculated by dividing the waist $(\mathrm{cm})$ over height $(\mathrm{cm})$ and a value of $\geq 0.5$ indicates that the subject is at risk of cardiovascular events. The blood pressure $(\mathrm{mmHg})$ was measured on sitting position and the mean of three readings was taken. The difference between systolic and diastolic blood pressure represented the pulse pressure, and the mean arterial blood pressure is equal to diastolic blood pressure $+(1 / 3 \times$ pulse pressure $)$.

Venous blood samples drew from the patients, the sera separated by centrifugation $(3,000 \mathrm{rpm}$ for $15 \mathrm{~min})$ for determination of the Blood Urea Nitrogen (BUN), Serum Creatinine (Scr), and SBP-1. Estimated glomerular filtration rate (eGFR) was calculated by using the Cockraft and Gault equation adjusted to the body surface area $\left(\mathrm{ml} / \mathrm{min} / \mathrm{m}^{2}\right)$, and 4 variable modified diet in renal disease (4 v MDRD) equation $\left(\mathrm{ml} / \mathrm{min} / 1.73 \mathrm{~m}^{2}\right)$. Serum creatinine, BNU and electrolytes were determined in the laboratory of the hospital as routine investigations. Serum SBP-1 level was measured by using the ELISA technology according to the instruction of the manufacturer.

\section{Statistical analysis}

Statistical analyses were performed using SPSS version 20.0 and Excel 2003 program for Windows. The results were provided number, percentage and as mean \pm SD. Two-tailed independent two samples were used to compare between healthy subjects and patients with CKD. The area under the curve with $95 \%$ confidence intervals, sensitivity, specificity, and positive predictive value were determined taking the SBP-1 as a discriminator at the cut-off value of $1500 \mathrm{pg} / \mathrm{ml}$. The differences were considered statistically significant when $\mathrm{p} \leq 0.05$.

\section{Results}

Table 1 shows the characteristic features of participants enrolled in the study. The mean \pm SD of age was $55.8 \pm 12.9 \mathrm{y}$. Chronic pyelonephritis represented the most frequent cause of CKD which found in 39 patients, while hypertension is the general associated disease which present in 84 patients. More than one comorbidities was present in the patients. Family history of renal diseases was detected in $15.2 \%$ of patients (Table 1). Elevated blood pressure was found in different profiles as shown in Table 2. The mean blood pressure of patients with combined systolic and diastolic high blood pressure was $176.2 \pm 20.8 \mathrm{mmHg}(\mathrm{n}=50)$. The mean $\pm \mathrm{SD}$ of the BMI was $26.7 \pm 5.3 \mathrm{~kg} / \mathrm{m}^{2}$, and the WHeR was $0.588 \pm$ 0.083 . The mean values of BUN and Scr were $140.2 \mathrm{mg} / \mathrm{dl}$ and $6.14 \mathrm{mg} / \mathrm{dl}$, respectively (Table 3). Estimated GFR using Cockraft and Gault equation adjusted to the body surface area and $4 \mathrm{v}-\mathrm{MDRD}$ equation were $7.70 \pm 3.19$ and $8.74 \pm 4.12$ $\mathrm{ml} / \mathrm{min} / \mathrm{m}^{2}$, respectively (Table 3 ). The mean $\pm \mathrm{SD}$ of serum SBP-1 in CKD patients was significantly $(\mathrm{p}<0.001)$ higher than the corresponding value of healthy subjects $(2009 \pm 857.4 \mathrm{vs}$. $920.6 \pm 288.3 \mathrm{pg} / \mathrm{ml}$ ), respectively. A significant positive correlation between eGFR (calculated by 4v-DMRD) and serum levels of SBP-1 $(r=0.188, p=0.036, d f=123)$. Receiving operating characteristics test shows that the area under the curve of WHeR was significantly high taking the cut-off value of SBP-1 is $1500 \mathrm{pg} / \mathrm{ml}$ (Figure 1). The sensitivity, the specificity, and the positive predictive value of this discriminator were $61.6 \%, 100 \%$, and $77 \%$, respectively (Figure 1). 
Assessment of serum selenium binding protein-1 level in patients with chronic kidney disease: its relation to the renal function and the associated risk factors

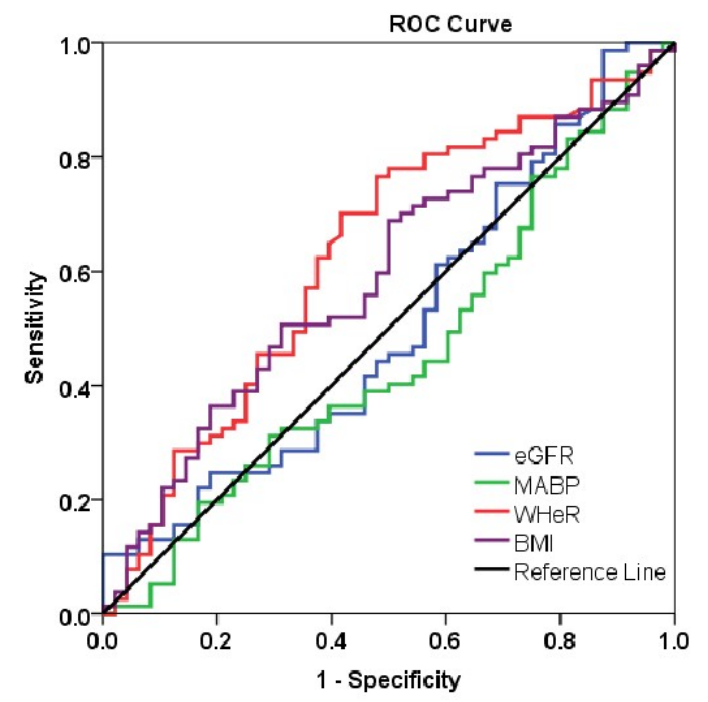

\begin{tabular}{llll}
\hline Variables & AUC & 95\% C.I. & p-value \\
\hline eGFR & 0.505 & $0.339-0.611$ & 0.925 \\
MABP & 0.457 & $0.352-0.562$ & 0.417 \\
WHeR & 0.630 & $0.527-0.732$ & 0.015 \\
BMI & 0.591 & $0.490-0.693$ & 0.086 \\
\hline
\end{tabular}

Figure 1. Area under the curve and 95\% confidence interval of the eGFR, MABP, WHeR, and BMI taking the SPBI as a discriminator with a cut-off value of $1500 \mathrm{pg} / \mathrm{ml}$. The sensitivity is $61.6 \%$ and the specificity is $100 \%$, and a positive predictive value is $77 \%$. eGFR: Estimated glomerular filtration rate $\left(\mathrm{ml} / \mathrm{min} / \mathrm{m}^{2}\right), A B P$ : Mean arterial blood pressure (mmHg), WHeR: Waist to height ratio, BMI: Body mass index.

Table 1. Characteristics of the participants enrolled in the study.

\begin{tabular}{ll}
\hline Variables & Results \\
\hline Gender (Female: male) & $59: 66$ \\
\hline Age (y) & $55.8 \pm 12.9$ \\
\hline Total & $54.7 \pm 13.9$ \\
\hline Female & $56.0 \pm 16.6$ \\
\hline Male & $19(15.2)$ \\
\hline Family history of renal diseases & \\
\hline Causes of renal failure & $39(31.2)$ \\
\hline 1.Renal: & $06(4.8)$ \\
\hline Chronic pyelonephritis & $03(2.4)$ \\
\hline Chronic glomerulonephritis & $03(2.4)$ \\
\hline Analgesic induced nephropathy & $03(2.4)$ \\
\hline Bladder diseases & \\
\hline Renal cyst & \\
\hline Diabetes mellitus & \\
\hline
\end{tabular}

\begin{tabular}{ll}
\hline Hypertension & $84(67.2)$ \\
\hline Preeclampsia & $04(3.2)$ \\
\hline Trauma & $01(0.8)$ \\
\hline Shock & $01(0.8)$ \\
\hline Connective and rheumatic diseases & $04(3.2)$ \\
\hline 3. No identified cause & $04(3.2)$ \\
\hline $\begin{array}{l}\text { The results are expressed as number (percentage) and mean } \pm \text { SD of number } \\
\text { of the participants (n=125). }\end{array}$ \\
\hline
\end{tabular}

Table 2. Baseline of the blood pressure and anthropometric measurements.

\begin{tabular}{|c|c|}
\hline Blood pressure $(\mathrm{mmHg})$ & Data results \\
\hline Normotensive & $27(21.6)$ \\
\hline Systolic $\leq 139 \mathrm{mmHg}$ & $73(58.4)$ \\
\hline Diastolic $\leq 90 \mathrm{mmHg}$ & $25(20)$ \\
\hline Both systolic $\leq 139 \mathrm{mmHg}$ and diastolic $\leq 90 \mathrm{mmHg}$ & $125.5 \pm 11.9$ \\
\hline Systolic & $71.5 \pm 11.6$ \\
\hline Diastolic & $54.0 \pm 12.3$ \\
\hline Pulse & $89.3 \pm 10.2$ \\
\hline \multicolumn{2}{|l|}{ Mean } \\
\hline \multicolumn{2}{|l|}{ Hypertensive (isolated or combined) } \\
\hline Systolic $\geq 139 \mathrm{mmHg}$ & $98(78.4)$ \\
\hline Diastolic $\geq 90 \mathrm{mmHg}$ & $52(41.6)$ \\
\hline Isolated hypertensive (either systolic or diastolic) & $50(40)$ \\
\hline Systolic & $161.3 \pm 19.7$ \\
\hline Diastolic & $79.5 \pm 6.7$ \\
\hline Pulse & $81.8 \pm 20.9$ \\
\hline Mean & $106.5 \pm 7.8$ \\
\hline Both systolic $\geq 139 \mathrm{mmHg}$ and diastolic $\geq 90 \mathrm{mmHg}$ & $50(40)$ \\
\hline Systolic & $176.2 \pm 20.8$ \\
\hline Diastolic & $102.6 \pm 14.6$ \\
\hline Pulse & $73.6 \pm 19.2$ \\
\hline Mean & $126.9 \pm 14.3$ \\
\hline Body mass index $\left(\mathrm{kg} / \mathrm{m}^{2}\right)$ & $26.7 \pm 5.3$ \\
\hline Waist circumference (cm) & $94.4 \pm 13.6$ \\
\hline Waist to height ratio & $0.588 \pm 0.083$ \\
\hline
\end{tabular}

The results are expressed as number (percentage) and mean $\pm \mathrm{SD}$ of number of participants $(n=125)$.

Table 3. Renal function tests.

\begin{tabular}{ll}
\hline Renal function indices & Total \\
\hline Blood urea nitrogen $(\mathrm{mg} / \mathrm{dl})$ & $140.2 \pm 55.2$ \\
\hline
\end{tabular}




\begin{tabular}{ll}
\hline Serum creatinine $(\mathrm{mg} / \mathrm{dl})$ & $6.14 \pm 2.53$ \\
\hline Estimated glomerular filtration rate & $13.53 \pm 6.17$ \\
\hline (Cockraft and Gault): (ml/min) & $7.70 \pm 3.19$ \\
\hline Estimated glomerular filtration rate & \\
\hline (Cockraft and Gault): $\left(\mathrm{ml} / \mathrm{min} / \mathrm{BSA}\left(\mathrm{m}^{2}\right)\right)$ & $8.74 \pm 4.12$ \\
\hline Estimated glomerular filtration rate & \\
\hline (4 $\mathrm{v}$ MDRD): (ml/min $\left./ 1.73 \mathrm{~m}^{2}\right)$ & \\
\hline The results are expressed as mean $\pm \mathrm{SD}$. &
\end{tabular}

The results are expressed as mean \pm SD.

\section{Discussion}

The results of this study showed that the serum level of SBP-1 was significantly increased by 2.18 folds of health subjects, and it is a significant discriminator of WHeR in patients with CKD at a cut-off of $1500 \mathrm{pg} / \mathrm{ml}$. Chronic pyelonephritis per se or combined with other causes was the major predisposing cause of CKD. This observation is in agreement with other studies that parenchymal scarring and pyelonephritis were common findings in the nephroctomy specimens [20]. The higher percentage of diabetes mellitus that reported in this study explained the significant percentage of chronic pyelonephritis as an etiological cause of CKD [21]. The majority of patients had elevated blood pressure which may a cause or the late sequel of CKD. Calcification of the renal arteries or ageing led to high blood pressure, decrease GFR and thereby CKD [22]. The prevalence of uncontrolled elevated blood pressure is frequently observed in CKD as this study found that 50 patient had both systolic and diastolic high blood pressure [23]. The mean values of the body mass index and waist circumference were $26.7 \mathrm{~kg} / \mathrm{m}^{2}$ and $94.4 \mathrm{~cm}$ indicating that the patients represent over-weight with central obesity. This observation is in agreement with other studies that showed central obesity is a frequent observation in CKD [24]. Significant high WHeR which exceeded 0.5 indicates that the patients are at risk of cardiovascular events. Recent studies demonstrate that children with CKD gain a significant value of WHeR and prone to cardiovascular events [25]. Estimated glomerular filtration rate was determined by following three formulas and the results were comparable and indicate that the patients were at Grade $5 \mathrm{CKD}$ or renal failure. A significant extraordinary mean value of SBP-1 in patients with $\mathrm{CKD}$ is a novel observation that did not mention in the literatures. Recent review highlights SBP-1 as a useful marker to detect acute kidney injury [26]. Deficiency of glutathione peroxidase in CKD which counteracts the SBP-1 may explain the significant elevated level of SBP-11 [27]. This study demonstrates a significant increase of eGFR with SBP-1 which may suggest the effect of SBP-1 on the vascular smooth muscle. It is necessary to mention that the limits of eGFR were narrow which may be not precisely indicated that SBP-1 dilates the blood vessel. The results that obtained by receiving operating characteristics indicate that a cut-off value of $\geq 1500$ $\mathrm{pg} / \mathrm{ml}$ significantly discriminates the CKD patients with a high WHeR. This observation highlights the importance of determination of the SBP-1 because it can predict the risk factors of cardiovascular events. One of the limitations of the study represents the measurement of glutathione peroxidase which is missed to exclude the action of SBP-1 on the generation of ROS. We conclude that determination of SBP-1 is a useful marker of deterioration of renal function as it significantly and positively correlates with estimated glomerular filtration rate. A cut-off value of $1500 \mathrm{pg} / \mathrm{ml}$ can serve as a discriminator of cardiovascular events in chronic kidney disease by the evidence of a significant the area under the curve of waist to height ratio which is a risk factor of cardiovascular events.

\section{Acknowledgement}

The authors appreciate the Faculty of Pharmacy, Hawler Medical University for giving us the opportunity to complete this study.

\section{Author's Contribution}

S.D.S: Acquisition of data, revising the article critically for important intellectual content, final approval of the version to be published. A.N.Al-H: Acquisition of data, revising the article critically for important intellectual content, Final approval of the version to be published. M.S.Al-N: concept and design of study, analysis and interpretation of data, drafting the article, Final approval of the version to be published.

\section{References}

1. Torrealba JR, Colburn M, Golner S, Chang Z, Scheunemann T, Fechner JH, Roenneburg D, Hu H, Alam T, Kim HT, Kanmaz T, Oberley T, Knechtle SJ, Hamawy MM. Selenium-binding protein-1 in smooth muscle cells is downregulated in a rhesus monkey model of chronic allograft nephropathy. Am J Transplant 2005; 5: 58-67.

2. Porat A, Sagiv Y, Elazar ZA. $56 \mathrm{kDa}$ selenium-binding protein participates in intra-Golgi protein transport. J Biol Chem 2000; 275: 14457-14465.

3. Bansal MF, Mukhopadhyay $T$, Scott J, Cook RG, Mukhopadhyay R, Medina D. DNA sequencing of a mouse liver protein that binds selenium: implications for seleniums mechanism of action in cancer prevention. Carcinogenesis 1990; 11: 2071-2073.

4. Chang PW, Tsui SK, Liew C, Lee CC, Waye MM, Fung $\mathrm{KP}$. Isolation, characterization, and chromosomal mapping of a novel cDNA clone encoding human selenium binding protein. J Cell Biochem 1997; 64: 217-224.

5. Lanfear J, Fleming J, Walker M, Harrison P. Different patterns of regulation of the genes encoding the closely related $56-\mathrm{kDa}$ selenium- and acetaminophen-binding proteins in normal tissues and during carcinogenesis. Carcinogenesis 1993; 14: 335-340.

6. Silvers AL, Lin L, Bass AJ, Chen G, Wang Z, Thomas DG, Lin J, Giordano TJ, Orringer MB, Beer DG, Chang AC. Decreased selenium-binding protein 1 in esophageal adenocarcinoma results from posttranscriptional and 
epigenetic regulation and affects chemosensitivity. Clin Cancer Res 2010; 16: 2009-2021.

7. Zhang S, Li F, Younes M, Liu H, Chen C, Yao Q. Reduced selenium-binding protein 1 in breast cancer correlates with poor survival and resistance to the antiproliferative effects of selenium. PLoS One 2013; 8: e63702.

8. Yang $M$, Sytkowski AJ. Differential expression and androgen regulation of the human selenium-binding protein gene hSP56 in prostate cancer cells. Cancer Res 1998; 58: 3150-3153.

9. He QY, Cheung YH, Leung SY, Yuen ST, Chu KM, Chiu JF. Diverse proteomic alterations in gastric adenocarcinoma. Proteomics 2004; 4: 3276-3287.

10. Sawiris GP, Sherman-Baust CA, Becker KG. Development of a highly specialized cDNA array for the study and diagnosis of epithelial ovarian cancer. Cancer Res 2002; 62: 2923-2928.

11. Scortegagna M, Martin RJ, Kladney RD, Neumann RG, Arbeit JM. Hypoxia-inducible factor-1 $\alpha$ suppresses squamous carcinogenic progression and epithelialmesenchymal transition. Cancer Res 2009; 69: 2638-2646.

12. Yao Y, Schroder J, Karlsson H. Verification of proposed peripheral biomarkers in mononuclear cells of individuals with schizophrenia. J Psychiat Res 2008; 42: 639-643.

13. Kanazawa T, Glatt SJ, Faraone SV, Hwu HG, Yoneda H, Tsuang MT. Family-based association study of SELENBP1 in schizophrenia. Schizophr Res 2009; 113: 268-272.

14. Fang W, Goldberg ML, Pohl NM, Bi X, Tong C, Xiong B, Koh TJ, Diamond AM, Yang W. Functional and physical interaction between the selenium-binding protein 1 (SBP1) and the glutathione peroxidase 1 selenoprotein. Carcinogenesis 2010; 31: 1360-1366.

15. Wu M, Kang MM, Schoene NW, Cheng WH. Selenium compounds activate early barriers of tumorigenesis. J Biol Chem 2010; 285: 12055-12062.

16. Witko Sarsat V, Friedlander M, Capeillere Blandin C, Nguyen-Khoa T, Nguyen AT, Zingraff J, Jungers P, Descamps-Latscha B. Advanced oxidation protein products as a novel marker of oxidative stress in uremia. Kidney Int 1996; 49: 1304-1413.

17. Epperlein MM, NouroozZadeh J, Jayasena SD Hothersall JS, Noronha-Dutra A, Neild GH. Nature and biological significance of free radicals generated during bicarbonate hemodialysis. J Am Soc Nephrol 1998; 9: 457-463.

18. Pang P, Abbott M, Abdi M, Fucci QA, Chauhan N, Mistri M, Proctor B, Chin M, Wang B, Yin W, Lu TS, Halim A, Lim K, Handy DE, Loscalzo J, Siedlecki AM. Pre-clinical model of severe glutathione peroxidase-3 deficiency and chronic kidney disease results in coronary artery thrombosis and depressed left ventricular function. Nephrol Dial Transplant 2018; 33: 923-934.
19. Kim KS, Yang HY, Song H, Kang YR, Kwon J, An J, Son JY, Kwack SJ, Kim YM, Bae ON, Ahn MY, Lee J, Yoon $\mathrm{S}$, Lee BM, Kim HS. Identification of a sensitive urinary biomarker, selenium-binding protein 1 , for early detection of acute kidney injury. J Toxicol Environ Health A 2017; 80: 453-464.

20. Noroozinia F, Makhdoomi K, Behnamfard H, Mohammadi S, Dindarian S Bagheri M, Mohammadi H. The pathological evaluation of nonneoplastic kidney disorder in tumor nephrectomy specimens. Saudi J Kidney Dis Transpl 2018; 29: 586-590.

21. Enshaei A, Boora AA, Taheri D, Changizi Z, Bahmani N. Focal xanthogranulomatous pyelonephritis with pulmonary lesions on the background of type two diabetes mellitus. Case Rep Radiol 2018; 2018: 1698286.

22. Phan O, Burnier M, Wuerzner G. Hypertension in chronic kidney disease-role of arterial calcification and impact on treatment. Eur Cardiol 2014; 9: 115-119.

23. Zheng Y, Tang L, Zhang W, Zhao D, Zhang D, Zhang L, Cai G, Chen X, Patriotic Collaborative Group. Applying the new intensive blood pressure categories to a nondialysis chronic kidney diseasepopulation: the prevalence, awareness and treatment rates in chronic kidney disease patients with hypertension in China survey. Nephrol Dial Transplant 2018.

24. Dierkes J, Dahl H, Lervaag Welland N, Sandnes K, Sæle K, Sekse I, Marti HP High rates of central obesity and sarcopenia in CKD irrespective of renal replacement therapy-an observational cross-sectional study. BMC Nephrol 2018; 19: 259.

25. Sgambat K, Roem J, Mitsnefes M, Portale AA, Furth S, Warady B, Moudgil A. Waist-to-height ratio, body mass index, and cardiovascular risk profile in children with chronic kidney disease. Pediatr Nephrol 2018.

26. Beker BM, Corleto MG, Fieiras C, Musso CG. Novel acute kidney injury biomarkers: their characteristics, utility and concerns. Int Urol Nephrol 2018; 50: 705-713.

27. Wong FN, Tan JA, Keng TC, Ng KP, Chua KH, Kuppusamy UR. Association between plasma soluble RAGE and renal function is unaffected by medication usage and enzymatic antioxidants in chronic kidney disease with type 2 diabetes. Clin Chim Acta 2016; 453: 56-61.

\section{*Correspondence to}

Marwan S. Al-Nimer

Hawler Medical University

Erbil

Iraq 